\title{
Fermentasi Alang-Alang sebagai Pakan Ternak Kerbau Rawa
}

\author{
Fermented Imperata cylindrical as Swamp Buffalo Feed \\ J. Laksono* dan W. Ibrahim
}

\author{
Program Studi Peternakan, Fakultas Peternakan, Universitas Musi Rawas \\ *Corresponding Author: judolaksono@gmail.com
}

\begin{abstract}
The objectives of this study see nutritional quality of Imperata cylindrica, which is fermented as feed swamp buffalo. This research was conducted at the Laboratory of Agriculture, Musi Rawas University from June to September 2020. This study used an experimental method with a non-factorial completely randomized design (CRD). The treatment factors are as follows L0: Banana Weevil Mol $20 \mathrm{ml}$, L1 : Banana Weevil Mol $25 \mathrm{ml} \mathrm{L2}$ : Banana Weevil Mol 30 ml, L3 : Banana Weevil Mol 35 ml, L4: Banana Weevil Mol 40 ml, L5 : Banana Weevil Mol $45 \mathrm{ml}$, L6 : Banana Weevil Mol $45 \mathrm{ml}$. The data in this study will be analyzed using analysis of variance (ANOVA), if there is a significant difference between treatments, the Least Significant Difference (LSD) test will be carried out. Based on the analysis of variance, it shows that processing Imperata cylindrica, as animal feed for swamp fermentation based very real effect $(\mathrm{P}<0.01)$ on parameter $(\mathrm{pH})$, Crude Protein, have a real impact $(\mathrm{P}<0.05)$ on crude fiber treatment and no significant effect $(\mathrm{P}>0.05)$ on parameters of moisture content and dry matter The results of the research conducted showed a positive effect on the decrease in $\mathrm{pH}$, increase the value of crude protein and reduce the content of gauze fiber in a fermented Imperata cylindrica, as swamp buffalo fodder.
\end{abstract}

Key words: reeds, fermentation, banana hump mole, swamp buffalo

\begin{abstract}
ABSTRAK
Penelitian ini bertujuan untuk mengetahui kualitas nutrisi alang-alang yang di fermentasi sebagai pakan ternak kerbau. Penelitian ini dilaksanakan di Laboratorium Fakultas Pertanian Universitas Musi Rawas pada bulan Juni sampai dengan bulan September 2020. Penelitian ini menggunakan metode Eksperimental dengan Rancangan Acak Lengkap (RAL) Non Faktorial. Adapun faktor perlakuan sebaga iberikut. L1 : Mol Bonggol Pisang $20 \mathrm{ml}$, L2 : Mol Bonggol Pisang 25 ml, L3 : Mol Bonggol Pisang $30 \mathrm{ml}$, L4 : Mol Bonggol Pisang $35 \mathrm{ml}$, L5 : Mol Bonggol Pisang $40 \mathrm{ml}$, L6 : Mol Bonggol Pisang $45 \mathrm{ml}$. Data yang penelitian ini akan di analisis menggunakanan alisisis ragam (ANOVA), jika terdapat perbedaan yang nyata antara perlakuan maka akan dilakukan uji Beda Nyata Terkecil (BNT). Berdasarkan analisa ragam, menunjukkan bahwa pengolahan alang - alang sebagai pakan ternak kerbau rawa berbasis fermentasi berpengaruh sangat nyata $(\mathrm{P}<0.01)$ pada parameter $(\mathrm{pH})$, Protein Kasar, berpengaruh nyata $(\mathrm{P}<0.05)$ pada perlakuan serat kasar dan berpengaruh tidak nyata $(\mathrm{P}>0.05)$ pada parameter kadar air dan bahan kering. Hasil penelitian yang di lakukan menunjukan pengaruh positif terhandap penurunan $\mathrm{pH}$, menaikan kandungan nilai protein kasar dan menurunkan kandungan serat kasar pada fermentasi alang-alang sebagai pakan ternak kerbau rawa.
\end{abstract}

Kata kunci : Alang-alang, Fermentasi, Mol bonggol Pisang, Kerbau Rawa

\section{PENDAHULUAN}

Salah satu ternak ruminansia yang habitatnya di daerah rawa yaitu ternak kerbau (Bubalus bubalis Linn.), dimana populasinya berada di Pulau Kalimantan dan pulau Sumatara. Ternak kerbau memiliki potensi yang baik dalam penyediaan daging konsumsi masyarakat dan tenaga untuk bidang pertanian, dimana kerbau juga dapat mengkonsumsi pakan yang memiliki kandungan nutrisi yang rendah Ali et al. (2013).

Populasi kerbau pada saat sekarang ini untuk indonesia pada tahun 2016 populasinya sebanyak 1.355.124 ekor dan tahun 2017 populasinya sebanyak 1.321 .904 ekor .Untuk di wilayah Sumatra Selatan pada tahun 2016 populasinya sebanyak 37.405 dan tahun 2017 populasinya sebanyak 30.840 ekor, untuk wilayah kabupaten Musi Rawas Urata sendiri pada tahun 2016 populasinya sebanyak 4.432 dan pada tahun 2017 populasinya sebanyak 4.249 ekor. Dengan data di atas dapat diketahui adanya penurunan populasi kerbau yang ada di Indonesia dengan jumlah penurunan 33.220 ekor, menurut BPS (2019).

Pengembangan ternak ruminansia dapat berjalan dengan baik jika kebutuhan akan hijauan pakan tersedia. Penyediaan pakan secara berkelanjutan dalam arti jumlah yang cukup dan 
kualitas yang baik merupakan salah satu faktor yang sangat mempengaruhi produktivitas ternak ruminansia (Laksono dan Karyono, 2017). Permasalahan dalam penyediaan pakan ternak yang berkualitas adalah ketersedia hijauan pakan yang semakin lama semakin terbatas baik secara kualitas maupun kuantitasnya, akibatnya berkurangnya lahan yang digunakan untuk sektor pertania. Banyaknya lahan pertanian yang sudah dialih fungsikan menjadi perkebunan kelapa sawit, karet dan ruko dan perumahan (Laksono dan Ibrahim, 2020).

Pemanfaatan hijauan pakan ternak yang dapat sebagai sumber pakan ternak kerbau rawa adalah alang- alang (Imperata cylindrica), alangalang merupakan tanaman gulma yang dapat tumbuh di daerah terbuka, bekas bakaran. Di Indonesia alang-alang yang potensinya sangat besar sering dianggap sebaga itumbuhan penggangu (gulma), sama sekali tidak diharapkan kehadirannya bahkan menimbulkan masalah serius yang pernah diangkat menjadi masalah nasional dalam pengembangan lahan pertanian. Kandungan nutrisi dari alang-alang (Imperata cylindrica), terdiri dari proten kasar $2,8 \%$, serat kasar 35,7\%, abu 5,42\%, ekstraaktif 3,6\%, Lignin $15,22 \%$, Selulosa 44,28 \%, Hemi selulosa $28,58 \%$. Wibisono, (2011)

Solusi yang dapat di tawarkan dalam penelitian ini adalah kandungan lignin, selulosa dan hemi selulosa pada alang-alang yang cukup tinggi menjadi factor pembatas utama kecernaan. Untuk dapat meningkatkan kecernaan dari alangalang (Imperata cylindrica) sebgai pakan ternak kerbau terlebih dahulu menurunkan kadar lignin, selulosa dan hemi selulosa dengan menggunakan bacteri asam laktat (BAL). Bakteri yang akan digunakan berasal dari tanamam pisang yaitu bonggol pisang, yang dilakukan secara fermentasi. Beberapa cara untuk menurunkan serat kasar tinggi yaitu amoniasi, silase dan fermentasi (Nurhayati et al., 2013). Berdasarkan permasalahan yang ada diatas penelitian ini dilakukan.

\section{MATERI DAN METODE}

Penelitian ini akan dilaksanakan di Laboratorium Fakultas Pertanian Universitas Musi Rawas, pada bulan Juni sampai dengan bulan September 2020. Alat-alat yang di gunakan dalam penelitian ini, adalah: timbangan, parang, ember plastik, timbangan digital, spidol, oven, blender, $\mathrm{pH}$ meter. Bahan-bahan yang digunakan adalah alang- alang, dedak, mol bonggo pisang, gula merah, air, terpal plastik, kertas label. Alangalang yang telah dipotong kemudian dilayukan dengan kadar airnya berkurang $\pm 70 \%$, kemudian ditimbang sebanyak $1 \mathrm{~kg}$ lalu dimasukan ke dalam baskom. Air yang digunakan yaitu $350 \mathrm{ml}$ kemudian ditambahkan MOL dengan dosis sesuai dengan perlakuan, dicampurkan dengan merata setelah itu masukan ke dalam kantong plastik ukuran $28 \mathrm{~cm}$ x $65 \mathrm{~cm}$ dan diikat kuat dalam kondisi an-aerob dengan kadar air lebih kurang $60 \%$. Fermentasi berakhir setelah 21 hari pemeraman dengan cara membuka masing masing kantong plastik yang berisi alang-alang (Imperata cylindrica) dikeluarkan untuk diangin - anginkan selama 1-2 jam.

Penelitian ini menggunakan metode Eksperimental dengan Rancangan Acak Lengkap (RAL) Non Faktorial terdiridari 6 perlakuan, dimana masing-masing perlakukan di ulang 3 kali. Adapun factor perlakuan sebagai berikut. L1 : Mol Bonggol Pisang $20 \mathrm{ml}$, L2 : Mol Bonggol Pisang $25 \mathrm{ml}$, L3 : Mol Bonggol Pisang $30 \mathrm{ml}$, L4 : Mol Bonggol Pisang $35 \mathrm{ml}$, L5 : Mol Bonggol Pisang $40 \mathrm{ml}$, L6 : Mol Bonggol Pisang $45 \mathrm{ml}$. Data yang penelitian ini akan di analisis menggunakan analisisi ragam (ANOVA), jika terdapat perbedaan yang nyata antar perlakuan maka akan dilakukan uji Beda Nyata Terkecil (BNT)

\section{HASIL DAN PEMBAHASAN}

Berdasarkan analisa ragam, menunjukkan bahwa pengolahan alang - alang sebagai pakan ternak kerbau rawa (Buffelus asiaticus ) berbasis fermentasi berpengaruh sangat nyata $(\mathrm{P}<0.01)$ pada parameter $(\mathrm{pH})$, Protein Kasar, berpengaruh nyata $(\mathrm{P}<0.05)$ pada perlakuan serat kasar dan berpengaruh tidak nyata $(\mathrm{P}>0.05)$ terhadap parameter kadar air dan bahan kering.

\section{pH}

Hasil analisis ragam menunjukan bahwa alang alang yang di fermentasi berpengaruh sangat nyata $(\mathrm{P}<0,01)$ terhadap $\mathrm{pH}$, hal ini di duga karena stater yang di gunakan dalam penelitian ini menggunakan mol bonggol pisang, dimana mol bonggol pisang banyak mengandung bakteri asam laktat. Dengan adanya bakteri asam laktat dalam proses fermentasi dapat menurunkan $\mathrm{pH}$ dari alang-alang yang difermentasi ini sesuai dengan pendapat Laksono dan Karyono (2020) 
Tabel 1. Rata-rata Perlakuan Alang - alang yang di Fermentasi Terhadap (pH), Kadar Air, Bahan Kering

\begin{tabular}{cccc}
\hline Perlakuan & $\mathrm{pH}$ & Kadar Air & Bahan Kering \\
\hline L0 & $4,55 \pm 0,50 \mathrm{cC}$ & $8,25 \pm 0,42$ & $91,74 \pm 0,42$ \\
L1 & $4,50 \pm 0,46 \mathrm{cC}$ & $8,16 \pm 0,34$ & $91,84 \pm 0,34$ \\
L2 & $4,36 \pm 0,20 \mathrm{bcBC}$ & $8,11 \pm 0,35$ & $91,88 \pm 0,35$ \\
L3 & $3,48 \pm 0,20 \mathrm{aA}$ & $8,14 \pm 0,26$ & $91,86 \pm 0,26$ \\
L4 & $3,57 \pm 0,17 \mathrm{aA}$ & $8,13 \pm 0,18$ & $91,87 \pm 0,18$ \\
L5 & $3,70 \pm 0,16 \mathrm{abAB}$ & $7,90 \pm 0,09$ & $92,26 \pm 0,39$ \\
\hline
\end{tabular}

Keterangan :Angka-angka yang diikuti oleh huruf yang sama pada setiapkolommenunjukanperbedaantidaknyata pada taraf 5\% (huruf kecil) dan $1 \%$ (huruf besar)

menyatakan bahwa bakteri asam laktat yang terdapat didalam stater, dapat membantu menurunkan $\mathrm{pH}$ selama proses ensilaseber langsung. Berdasarkan uji lanjut menunjukan perlakuan bahwa L0 merupakan perlakukan teringgi dengan rata-rata 4,55 terhadap parameter $\mathrm{pH}$. Hal ini diduga karena fermentasi alang-alang yang dilakukan tidak menggunakan stater mol bonggol pisang, sehingga bakteri asam laktat yang berkerja sebagai pengurai bahan menjadi lebih sedikit. Mirni et al. (2012) kualitas silase dapat dikatagorikan berdasarkan $\mathrm{pH}$ yaitu 3,5-4,2 baik sekali, 4,2-4,5 baik, 4,5-4,8 sedang dan lebih dari 4,8 adalah jelek. Perlakuan L3 merupakan perlakuan terendah dengan rata - rata 3,48 terhadap parameter $\mathrm{pH}$, hal ini diduga karena adanya kerja bakteri asam laktat yang berasal dari stater mol bonggol pisang. Sehingga selama ensilase berjalan terjadinya suasana asam, suasana asam ini terjadi adanya proses oksidasi etanol menjadi asetildehid dari stater mol bonggol pisang yang kemudian dioksidasi menjadi asam laktat. Hal ini sesuai dengan pendapat Sebayang (2006) bahwa keadaan asam dari hasil fermentasi silase disebabkan oleh teroksidasinya etanol menjadi asetildehid yang selanjutnya mengalami oksidasi lanjutan menjadi asam laktat.

\section{Kadar air (KA)}

Hasil analisis ragam menunjukan bahwa alang- alang yang di fermentasi berpengaruh tidak nyata $(\mathrm{P}>0,05)$ terhadap kadar air. Hal ini diduga karena dengan adanya penambahan stster mol bonggol pisang belum mampu memacu meingkatkan kadar air pada fermentasi alang alang. Peningkatan kadar air selama proses fermentasi akan berkorelasi terhadap peningkatan bahan kering. Semakin tinggi kadar air yang di hasilkan makan akan berpengaruh terhadap terhadap kehilangan bahan kering. Surono et al., (2006) menyatakan bahwa peningkatan level aditif diduga memacu aktivitas fermentasi sehingga menyebabkan produksi $\mathrm{H} 2 \mathrm{O}$ juga meningkat.

\section{Bahan kering (BK)}

Hasil analisis ragam menunjukan bahwa alang- alang yang di fermentasi berpengaruh tidak nyata $(\mathrm{P}>0,05)$ terhadap bahan kering. Hal ini diduga karena selam proses fermentasi kerja bakteri asam laktak belum maksimal walaupun starter yang di berikan terdiri dari beberapa level, apabila bakteri asam laktat berkerja dengan maksimal menyebabkan kehilangan bahan kering.

Tabel 2. Rata-rata perlakuan alang - alang yang di fermentasi terhadap protein kasar dan serat kasar

\begin{tabular}{ccc}
\hline Perlakuan & Protein Kasar & Serat Kasar \\
\hline L0 & $5,75 \pm 0,33 \mathrm{aA}$ & $30,5 \pm 0,78 \mathrm{~b}$ \\
L1 & $6.03 \pm 0,10 \mathrm{abAB}$ & $29,9 \pm 0,57 \mathrm{ab}$ \\
L2 & $6,43 \pm 0,44 \mathrm{bcBC}$ & $29,5 \pm 0,53 \mathrm{a}$ \\
L3 & $6,73 \pm 0,57 \mathrm{cC}$ & $29,3 \pm 0,47 \mathrm{a}$ \\
L4 & $6,91 \pm 0,08 \mathrm{cC}$ & $29,2 \pm 1,30 \mathrm{a}$ \\
L5 & $6,68 \pm 0,21 \mathrm{cC}$ & $28,7 \pm 0,43 \mathrm{a}$ \\
\hline
\end{tabular}

Keterangan :Angka-angka yang diikuti oleh huruf yang sama pada setiapkolommenunjukanperbedaantidaknyata pada taraf 5\% (huruf kecil) dan 1\% (huruf besar)

Selain itu juga pengaruh dari respirasi terhadap proses fermentasi akan menyebabkan kandungan nutrien terurai kemudian akan menurunkan kandungan bahan kering, sedangkan selama proses fermentasi akan menghasilkan bakteri asam laktat dan air lebih besar dalam ensilase tersebut. Anggraeny et al. (2009) berpendapat bahwa semakin banyak kehilangan bahan kering atau peneingkatan kadar air di akibatkan adanya bahan yang diensilase 
membutuhkan panas semakin banyak, agar dapat meningkatkan suhu silase serat kasar dan berpengaruh tidak nyata $(\mathrm{P}>0.05)$ pada parameter kadar air dan bahan kering.

\section{Protein kasar (PK)}

Hasil analisis ragam menunjukan bahwa alang- alang yang di fermentasi berpengaruh sangat nyata $(\mathrm{P}<0,01)$ terhadap protein kasar. Hai ini diduga karena adany kerja bakteri asam laktat yang berasal dari mol bonggol pisang yang menyebkan terjadinya proses ensilase dimana terjadinya suasana anaerob dan asam sehingga dapat mendegradasi ikata lignin, selulosa dan hemiselulosa menjadi ikatan yang lebih sederhana selama proses fermentasi. Proses terjadinya perubahan ini disebut ensilase terjadi apabila oksigen telah habis dipakai, pernafasan tanaman akan berhenti dan suasana menjadi anaerob (Kojo, 2015). Selain itu juga peningkatan kandungan protein kasar di sebabkan adanya perlakuan fisik yang dilakukan sebelum di lakukan fermen tasi pada alang alang. Hal ini sesui dengan pendapat Laksonodan Ibrahim (2020) menyatakan peningkatan kandungan proteinkasar juga akibat adanya aktivitas fisik yaitu penyacahan dan aktivitas kimia yaitu penambahan urea dan aktifitas biologi dengan penambahan mikroorganisme lokal (MOL) bonggol pisang.

Berdasarkan uji lanjut menunjukan bahwa L0 merupakan perlakukan terendah dengan ratarata $5,75 \%$ terhadap protein kasar. Hal ini diduga karena pada perlakuan ini tampa di berikan mol bonggol pisang, sehingga bakteri asam laktat hanya sediki sekali sehingga menyebakan tidak meningkatnya kandungan protein kasar. Sesuai dengan pendapat Santi (2018) menyatakan bahwa meningkatnya jumlah mikroba maka kadar protein kasar pakan fermentasi akan mengalami peningktan. Pada L4 perlakuan tertinggi dengan nilai rata-rata $6,91 \%$ terhadap parameter protein kasar. Hal ini diduga karena adanya pemberian stater mol bonggol pisang yang mengandung bakteri asam laktat yang dapat merombak bahan organik seperti selulosa dan hemiselosa menjadi ikatan yang lebih sederhana sehingga meningkatkan dangungan protein kasar alangalang Karyono dan Laksono (2019) Untuk meningkatkan unsur hara danmempercepat hasil fermentasi bahan maka diperlukan penambahanaktivator seperti MOL bongkol pisang yang terdapat bakteri asam laktat yang dapat merombak bahan organik. Dapat kita lihat adanya peningkatan kandungan protein kasar berdasarkan literatur protein kasar 2,8\% setelah di lakukan fermentasi dengan penambahan mol bonggol pisang nak menjadi 6,91\%, selain penambahan mol peningkatan kandungan protein disebabkan juga karena adanaya perlakuan fisik, kima dan biologi. Menurut pendapat Utomo (2015), perlakuan yang diberikan pada hasil sisa tanaman pertanian atau perkebunan, dapat dilakukan pengolahan secara fisik, kima dan biologi untuk meningkatkan kandungan nutrisi

\section{Serat kasar (SK)}

Hasil analisis ragam menunjukkan bahwa alang- alang yang difermentasi berpengaruh nyata $(\mathrm{P}<0,05)$ terhadap serat kasar. Hal ini diduga karena bakteri asam laktat yang berasal dari stater mol bonggol pisang memberikan dampak yang positif terhadap pendegradasi dan perombak lignin, selulosa dan hemiselulosa pada proses fermentasi alang-alang. Dalam proses fermentasi dapat memutuskan ikatan lignin dan silica dengan selulosa dan hemiselulosa sehingga dapat menurunkan kandungan serat kasar dan lebih mudah dicerna. Antonius (2010).

Berdasarkan uji lanjut menunjukan bahwa L5 merupakan perlakuan terendah dengan nilai ratarata $28,7 \%$ terhadap serat kasar. Hal ini di duga karena tejadinya pendegredasian bahan selam proses ensilase berlangsung oleh bakteri asam laktat serta memecahkan ikatan serat serta, melarutkan silika dan lignin yang terdapat dalam dinding sel pada bahan pakan berserat. Menurut Komar (1984) penurunan kadar serat kasar terjadi karena perlakuan fermentasi yang menyebabkan perubahan dinding sel. Pada perlakuak L0 merupakan perlakuan tertinggi dengan nilai ratarata $30,5 \%$. Hal ini diduga karena tidak diberikannya stater mol bonggol pisang sehingga proses perombakan pada bahan menjadi lambat. Penggunaan statater berupa mol bonggol pisang sangat di perlukan dalam proses ensilase dimana dengan adanya penambahan stater mol bonggol pisang, mampu mendegradasi dan mampu memecahkan ikatan lignoselulosa dan lignohemiselulosa. Hal ini sesuai dengan pendapat Ridwan et al. (2006) menyatakan bahwa penambahan inokulum akan semakin memper cepat proses fermentasi dan semakin banyak substrat yang didegradasi. Proses fermentasi dapat meningkatkan ketersediaan zat- zat makanan seperti protein dan energi metabolis serta mampu memecah komponen kompleks menjadi komponen sederhana (Zakariah, 2012). 


\section{KESIMPULAN}

Hasil penelitian yang dilakukan menunjukan pengaruh positif terhandap penurunan $\mathrm{pH}$, menaikan kandungan nilai protein kasar dan menurunkan kandungan serat kasa pada fermentasi alang-alang sebagai pakan ternak kerbau rawa.

\section{UCAPAN TERIMAKASIH}

Terima Kasih disampaikan Kepada Direktorat Riset dan Pengabdian Kepada Masyarakat Direktorat Jendral Pegguatan Riset dan Pengembangan Kementrian Riset Teknologi dan Pendidikan Tinggi Republik Indonesia dalam Hibah Penelitian Dosen Pemula Nomor : 8/E/KPT/2020

\section{DAFTAR PUSTAKA}

Antonius, 2010. Pengaruh pemberian jerami padi terfermentasi terhadap palatabilitas kecernaan serat dan digestible energy ransum sapi. Seminar Nasional Teknologi Peternakan dan Veteriner. 224-228

Ali , A. I. M, S. Sandi, Muhakka, Riswandi, D. Budianta. 2013. The Grazing of Pampangan Buffaloes at Non Tidal Swamp in South Sumatra of Indonesia. APCBEE Procedia. 8 : 87-92

BPS. Badan Pusat Statistik Nasional, 2019 Populasi ternak di Sumatra Selatan https://www.bps.go.id/subject/24/peternak an.html (Diakses Juli 2019)

Karyono, T., J. Laksono, 2019 Kualitas fisik kompos feses sapi potong dan kulit kopi dengan penambahan aktivator Mol Bongkol Pisang dan EM4 Jurnal Peternakan Indonesia, 21 (2): 154-162

Komar, A., 1984. Teknologi pengolahan jerami padi sebagai pakan ternak. Dian Grahita. Bandung.

Kojo., 2015. Pengaruh penambahan dedak padi dan tepung jagung terhadap kualitas fisik silase rumput gajah. Jurnal Zootek. 35 (1) : 21-29

Laksono, J., T. Karyono 2017 Pemberian pupuk fosfat dan mikoriza albuskular terhadap pertumbuhan tanaman legum (Indigofera zellingeriana). Jurnal Sain Peternakan

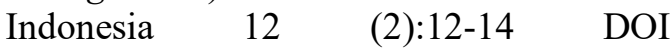
:https://doi.org/10.31186/jspi.id.12.2.184$\underline{190}$

Laksono, J., W. Ibrahim. 2020. Pengaruh metode pengolahan dan waktu pemeraman pelepah sawit terhadap kualitas nutrisi pakan ternak kerbau rawa (Buffelus asiaticus). Jurnal Ilmiah Peternakan Terpadu 8 (1): 27-31, DOI: http://dx.doi.org/10.23960/jipt.v8i1.p27$\underline{32}$.

Laksono, J., T. Karyono. 2020 Pemberian Level Starter Pada Silase Jerami Jagung dan Legum Indigofera zollingeriana terhadap Nilai Nutrisi Pakan Ternak Ruminansia Kecil. Jurnal Peternakan ( Jurnal of Animal Science). $04 \quad(01) \quad: \quad 33-38$ DOI :http://dx.doi.org/10.31604/jac.v4i1.1420

Mirni, L., Ismudiono, S. Koesnoto, S. Chuniati, N. Hidayati, E.V.F Vina (2012). Kareteristik pucuk tebu (Saccharum offcinarum Linn) dengan penambahan Lactobacillus plantarum. Agroveteriner 01 (01) : 5-10

Nurhayati, T., Y. Mas'udah, dan S. Sarudji. 2013. The Content of crude crotein and crude fiber palm oil fronds fermentedby xylanolitic bacteria (Bacillus pumilus) Agroveteriner. 1(2):73-78

Ridwam, R., S. Ratnakomala, G. Kartina, Y. Widyastuti. 2005. Pengaruh Penambahan dedak padi dan Lactobacillus planlarum 1BL-2 dalam pembuatan silase rumput gajah (Pennisetum purpureum). Media Peternakan 28 (03) : 117-123.

Sebayang, F. 2006. Pembuatan etanol dari molases secara fermentasi menggunakan sel Saccharomyces cerevisiae yang terimobilisasi pada kalsium alginat. Jurnal Teknologi Proses 5 (2) : 75-80

Santi. 2018. Kadar protein kasar dan serat kasar jagung kuning giling pada di fermentasi dengan EM-4 Pada level yang berbeda. Agrovita (Jurnal Ilmu Pertanian ) 3 (2) : 8486.

Surono, M. Soejono, S.P.S. Budhi. 2006. Kehilangan bahan kering dan bahan organik silase rumput gajah pada umur potong dan level aditif yang berbeda. Journal of the Indonesian Tropical Animal Agriculture 31 (01) : 62-67.

Anggraeny, Y.N., dan U. Umiyasih. 2009. Pengarug fermentasi cerevision terhadap kandungan nutrisi dan kecernaan ampas aren (Arenga pinata Merr). Teknologi Peternakan dalam Seminar Nasional dan Veteriner. Hal : 256-262. 
Utomo, R. 2015. Konservasi hijauan pakan ternak dan peningkatan kualitas bahan pakan berserat tinggi. Gajah Mada University Press. Yogyakarta.

Wibisono, I. , L. Hugo, Antaresi, Aylianawati. 2011. Pembuatan pulp dari alang-alang. Jurnal Widya Tekhnik 10 (1) :11-20.
Zakariah, M .A, 2012. Fermentasi Asam Laktat pada Silase. Fakultas Peternakan. Universits Gajah Mada. UGM Press. Yogyakarta. 